\title{
MEMBANGUN KONSEP ENTERPRENEURSHIP ISLAM
}

\author{
Nur Baladina \\ Jurusan Sosial Ekonomi, Fakultas Pertanian, Universitas Brawijaya, \\ Jalan Veteran Malang, email: baladinaa@gmail.com, Hp. 081803859749
}

\begin{abstract}
Islam is a religion that emphasizes work or charity. Islam doesn't want, or even hates the people who laze around. In the history, business ethos of muslim society surpasses than any nation in the world. Therefore, Arabic traders are recognized as acontroller of the business in many countries around the world. Prophet Muhammad SAW and most of the companions are also known as the traders and entrepreneurs abroad. To show how important the work or charity, al Quran often link the "faith" word with the "charity" word. Therefore, to achieve quality of life in the world and in the hereafter, Islam does not only teach his followers to "mahdah" worship (formal ritual such as prayer, zakat, hajj), but also greatly encouraged the people to work hard, of course under control. Faith and charity should interact each other. It means no matter how hard the work done, should always be within the framework of Islamic law. One of the hard work that is encouraged by Islam is entrepreneurship. The motivation of muslim entrepreneur must be horizontal and vertical characteristic. The horizontal is viewed in its driving to develop the potential and desire which always look for many benefits to others, while the vertical is intended to devote to Allah SWT.
\end{abstract}

Islam adalah agama yang sangat mementingkan kerja atau amal. Islam tidak menghendaki bahkan membenci orang yang bermalas-malasan. Dalam sejarahnya pun, etos bisnis umat Islam mengungguli etos bisnis bangsa manapun di dunia ini, sehingga pedagang Arab dikenal menguasai bisnis di banyak negara. Nabi Muhammmad SAW dan sebagian besar sahabat juga dikenal sebagai para pedagang dan entrepreneur mancanegara. Untuk menunjukkan betapa pentingnya kerja atau amal itu, al Quran seringkali menggandengkan kata iman dengan kata amal. Oleh karena itu, untuk meraih kesejahteraan hidup di dunia dan akhirat, Islam tidak hanya mengajarkan kepada pemeluknya 
untuk beribadah mahdah (ritual formal seperti sholat, zakat, haji), namun juga sangat mendorong umatnya untuk bekerja keras, tentunya secara terukur dan terkendali. Antara iman dan amal harus ada interaksi, artinya, betapapun kerasnya usaha yang dilakukan harus selalu dalam bingkai hukum Islam. Salah satu kerja keras yang didorong Islam adalah berwirausaha. Dalam berwirausaha, motivasi wirausahawan muslim harus bersifat horizontal dan vertikal. Secara horizontal terlihat pada dorongannya untuk mengembangkan potensi diri dan keinginannya senantiasa mencari manfaat sebanyak-banyaknya untuk orang lain, sementara secara vertikal dimaksudkan untuk mengabdikan diri kepada Allah SWT.

Key words: building, entrepreneurship, Islam

\section{Pendahuluan}

Dalam beberapa hal, orang Islam terkadang dituding malas dan miskin. Sungguh tudingan yang menyakitkan. Sayangnya, begitulah agaknya kenyataan yang ada. Dalam kurun satu abad terakhir, di banyak bidang percaturan politik, budaya, dan terutama ekonomi, kaum muslim jauh tertinggal dibandingkan dengan kelompok masyarakat lain di dunia. Para santri (muslim) Indonesia bakal menjadi elite pengusaha Indonesia di masa depan (Geertz, 1960: 106108). Seorang Antropolog dalam upaya untuk menyelidiki siapa di kalangan muslim yang memiliki etos entrepreneurship. Dalam penelitian itu ditemukan bahwa etos itu ada pada kaum santri yang ternyata umumnya memiliki etos kerja dan etos kewirausahaan yang lebih tinggi dari kaum abangan (Geertz, 1960: 24).

Di sisi lain, Islam adalah agama yang sangat mementingkan kerja atau amal. Islam tidak menghendaki bahkan membenci orang yang bermalasmalasan. Bahkan untuk menunjukkan betapa pentingnya kerja atau amal itu, al Quran seringkali menggandengkan kata iman dengan kata amal. Pandangan yang secara tegas mendorong manusia untuk mengembangkan etos kerja itu bersumber dari firman Allah yang artinya:

"... Sesungguhnya Allah SWT tidak akan mengubah keadaan suatu kaum sampai mereka sendiri mengubah apa yang terdapat dalam diri mereka sendiri (yakni motivasi, tekad, dan usaha mereka) ..." (QS Ar Ra'd:11).

Namun kenyataannya, dalam masyarakat Indonesia etos kerja ini belum sepenuhnya membudaya, artinya budaya kerja sebagian masyarakat Indonesia belum sepenuhnya sesuai untuk kehidupan modern. Tentunya ini tidak bisa dihubungkan dengan budaya Islam, karena budaya Islam menghendaki orang bekerja keras. Islam mengajarkan pemeluknya agar berwirausaha. 
Nabi Muhammad SAW dan sebagian besar sahabat adalah para pedagang dan entrepreneur manca negara. Tidak berlebihan karenanya bila dikatakan bahwa etos entrepreneurship sudah melekat dan inheren dengan diri umat Islam. Bukankah Islam adalah agama kaum pedagang, lahir di kota dagang, dan disebarkan ke seluruh dunia oleh kaum pedagang?

Sayangnya, umat Islam Indonesia sepertinya tidak begitu tertarik dengan berwirausaha. Umat kita lebih condong menjadi pegawai negeri. Akibatnya, sebagai umat mayoritas, kita jauh tertinggal dari umat lain dan menjadi bulan-bulanan dalam bisnis dan sebagai penonton dari kesuksesan wirausaha umat lain. Oleh karena itu, upaya membangun kembali semangat dan jiwa kewirausahaan umat Islam Indonesia merupakan sebuah keniscayaan yang tak bisa ditawar-tawar. Setidaknya, ada tiga dasar pemikiran mengapa rekonstruksi entrepreunership umat Islam menjadi penting .

Pertama, umat Islam sejak kelahirannya, memiliki jiwa dan etos kewirausahaan yang tinggi. Nabi Muhammad SAW dan sebagian besar sahabat adalah para pedagang dan entrepreneur manca negara. Proses penyebaran Islam ke berbagai penjuru dunia sampai abad $13 \mathrm{M}$, dilakukan oleh para pedagang muslim. Masuknya Islam ke Indonesia dan upaya penyebarannya di Asia Tenggara, juga dibawa oleh para pedagang tersebut. Bukti nyata hal ini terlihat bahwa di setiap pesisir pantai Indonesia dan Nusantara penduduknya beragama Islam. Dengan demikian, etos entrepreneurship sesungguhnya memang sangat melekat dan inheren dengan diri umat Islam.

Ajaran Islam sangat mendorong entrepreneurship pada umatnya. Oleh karena itu bagi seorang muslim, jiwa kewirausahaan tersebut seharusnya sudah menjadi bagian dari hidupnya. Islam mengajarkan kepada pemeluknya agar bekerja dan beramal, sebagaimana disebutkan dalam al Quran yang artinya:

"Bekerjalah kamu, maka Allah, Rasulnya dan orang beriman, akan melihat pekerjaanmu" (QS at Taubah: 105). Selain itu juga disebutkan:

"Apabila kamu telah melaksanakan shalat, maka bertebaranlah kamu di muka bumi dan carilah rezeki Allah dan ingatlah Allah sebanyak-banyaknya agar kamu beruntung" (QS al Jumuah: 10).

Dan masih banyak lagi hadits Nabi yang mendorong pengembangan semangat entrepreneurship, seperti "Hendaklah kamu berdagang, karena di dalamnya terdapat 90 persen pintu rezeki" (HR Ahmad). "Sesungguhnya sebaik-baik mata pencaharian adalah seorang pedagang (entrepreneur)" (HR Baihaqy)

Kedua, kondisi ekonomi umat Islam Indonesia sudah sekian lama terpuruk, maka perlu revitalisasi entrepreneurship umat Islam. Keprihatinan yang sangat mendalam tentang fenomena kemerosotan umat Islam di bidang 
ekonomi, Para wiraswastawan di bidang tenun, batik dan lainnya telah mengalami kemunduran karena tidak fit lagi dalam "seleksi alam", proses perekonomian bangsa yang mengarah pada kapitalisme komparador, dimana terjadi proses alienasi dan deprivatisasi ekonomi rakyat (Rais,1986:57-59).

Umat Islam sudah sangat letih dihadapkan pada kesulitan ekonomi yang panjang, problem kemiskinan dan keterbelakangan akibat termarginalkan dalam ekonomi dan bisnis. Kinilah saatnya mengembangkan dan membangun pengusaha-pengusaha pemerataan ekonomi yang dicita-citakan oleh umat Islam (pribumi) yang tangguh dalam jumlah besar. Tujuannya untuk mewujudkan cita-cita negara ini. Lebih dari itu, kinilah momentumnya membangun landasan yang kokoh, yakni memperbanyak pilar para pengusaha pribumi itu yang menyangga bangunan ekonomi bangsa.

Ketiga, kehadiran lembaga-lembaga perbankan dan keuangan syariah dewasa ini, hendaknya diimbangi dengan tumbuhnya para entrepreneur muslim. Tumbuhnya etos entrepreneurship yang tinggi, khususnya bagi generasi umat, akan berdampak positif terhadap kemajuan dan kebangkitan ekonomi umat sebagaimana yang terjadi di masa silam, sekaligus berdampak positif bagi lembaga perbankan dan keuangan itu sendiri. Karena itu, para pengusaha muslim hendaknya dapat memanfaatkan lembaga perbankan dan keuangan tersebut dalam mengembangkan usahanya.

\section{Kilas Balik Entrepreneurship Umat Islam di Indonesia}

Secara historis dan antropologis, umat Islam Indonesia memiliki naluri bisnis yang luar biasa. Penelitian para ahli sejarah dan antropologi menunjukkan bahwa pada masa sebelum penjajahan, para santri memiliki semangat dan gairah yang besar untuk terjun dalam dunia bisnis, sebagaimana yang diajarkan para pedagang muslim penyebar agama Islam. Hal ini mudah dipahami karena Islam memiliki tradisi bisnis yang tinggi dan menempatkan pedagang yang jujur pada posisi terhormat bersama Nabi, syuhada dan orang-orang sholih. Islam, sebagaimana disebut di atas, sangat mendorong entrepreurship (kewirausahaan) bagi umatnya. Karena itu, para santri adalah pioner kewirausahaan di kalangan pribumi.

Karena itu, tidak aneh bila di Indonesia suku-suku yang kuat tradisi keagamaannya, justru kuat pula tradisi perdagangannya. Suku-suku Banjar, Minangkabau, Makasar, dan Bugis, adalah suku-suku yang kuat pemahaman dan pengamalan keagamaannya dan juga dikenal sebagai niagawan yang piawai. Demikian pula pengusaha-pengusaha industri kretek, batik, dan kerajinan perak 
di beberapa daerah di Jawa, berasal dari keluarga-keluarga yang menghayati dan menerapkan secara lebih sungguh-sungguh ajaran dan nilai-nilai agama Islam dalam kehidupan pribadi dan sosialnya. Oleh karena tingginya etos entrepreneurship umat Islam Indonesia masa lampau, maka hampir semua peneliti mengakui bahwa kaum muslim memiliki jiwa entrepreneurship yang tinggi, melebihi kelompok manapun, termasuk etnis Tionghoa.

Dalam konteks sejarah dunia pun, etos bisnis umat Islam memang mengungguli etos bisnis bangsa manapun di dunia ini, sehingga pedagang Arab menguasai bisnis di banyak negara di dunia ini. Namun dalam sejarahnya, etos entrepreneurship tersebut mengalami penurunan dan degradasi. Tantangan bagi kita sekarang adalah bagaimana "membangunkan" umat Islam dari "tidurnya", bahwa sekarang zaman sudah berbeda, dan ukuran-ukuran kerja juga sudah berbeda. Melalui jiwa kewirausahaan di era kebangkitan ekonomi syariah ini, etos entrepreneurship umat Islam yang selama ini meredup dalam perjalanan sejarahnya hendaknya dapat bangkit kembali.

\section{Menilik Pribadi Rasulullah SAW Sebagai Enterpreneur}

Dalam rangka meraih kesejahteraan hidup di dunia dan akhirat, Islam tidak hanya mengajarkan kepada pemeluknya untuk beribadah mahdah (ritual formal seperti sholat, zakat, haji), tapi juga sangat mendorong umatnya untuk bekerja keras, kendati demikian bukan berarti tanpa kendali. Antara iman dan amal harus ada interaksi, artinya betapapun kerasnya usaha yang dilakukan, harus selalu dalam bingkai hukum Islam. Salah satu kerja keras yang didorong Islam adalah berwirausaha/enterpreneur (Pulungan, 2009: 12).

Dalam literatur Islam, sosok Nabi Muhammad SAW adalah seorang pribadi yang seluruh dimensi kehidupannya dikupas dan dikaji secara intensif dan mendalam, baik oleh sejarawan Islam maupun oleh tokoh-tokoh di luar pemikir Islam. Akan tetapi, kepeloporan dan ketokohan Nabi Muhammad SAW di dunia wirausaha, kreatifitasnya di dunia bisnis, serta suksesnya sebagai trader dalam usia 40 tahun, selalu luput dari kajian dan sentuhan yang mendalam. Dalam dunia modern, kewirausahaan/enterpreneurship baru muncul di akhir tahun tujuh puluhan dan berkembang serta mulai diajarkan di kampus-kampus Amerika, Eropa, Jepang, Korea dan Australia. Sementara dunia Islam (khususnya Indonesia) bergelut dengan politik, dan sibuk dalam kajian-kajian fiqih dan tasawuf, sehingga tidak mengherankan kalau kemudian ketokohan Nabi SAW di bidang wirausahaan lepas dari pengamatan.

Salah satu yang menarik dari kajian David Moors tentang kewirausahaan 
dalam bukunya The Enterprising, mengungkapkan bahwa ciri-ciri wirausaha adalah mengenai personality dan pelaku wirausaha itu sendiri, disamping lingkungan yang mendukungnya, juga tugas-tugas yang diemban oleh seorang wirausaha dan karir yang bisa dicapainya. Lebih lanjut, "The act of enterpreneurship is an act patterned after modes of coping with early childhood experiences". Personality atau kepribadian seorang wirausaha adalah sikap yang didapatkannya sejak masa kecil, yaitu sikap merdeka, bebas dan percaya diri (Syahrial, 2011: 76). Ketiga sikap ini sangat dipengaruhi oleh lingkungan kedua orang tua, dimana peran ibu yang begitu penuh dedikasi terhadap perkembangan anaknya, sangat berpengaruh. Pengaruh dari kedua orang tua juga bisa sangat menunjang atau bahkan merusak salah satu atau ketiga unsur kepribadian wirausaha seorang anak.

Dalam konteks Islam, Nabi Muhammad SAW adalah wirausahawan sejati yang memiliki kemerdekaan, kebebasan dan memupuk kepercayaan pada diri sendiri melalui pengalaman yang menyenangkan ketika hidup di pedalaman, dalam asuhan ibu susunya yaitu Halimah, serta masa pahit dan penuh kepedihan, karena terlahir sebagai seorang yatim dan ditinggal ibunya yaitu Aminah ketika ia baru berusia enam tahun. Muhammad kemudian dibesarkan oleh kakeknya, yang juga tidak begitu lama bersamanya. Abu Thalib, paman kandungnyalah kemudian mengambil alih pengasuhan atas Muhammad yang masih berusia kurang dari 9 tahun. Inilah modal psikologis yang paling kokoh sebagai landasan sikap, dan perilaku wirausahawan beliau di kemudian hari dan menjadi referensi penelitian para ahli kewirausahaan, seperti David G. Moore dan Orvis Colins, Abaham Zaleznik, Jhon Kao, dll. Dalam kitab Musnad Imam Ahmad juz 4 dan "The History of Islam" vol.1 diceritakan bahwa Muhammad baru berusia dua belas tahun ketika pergi ke Syria berdagang bersama Abu Thalib, pamannya. Ketika pamannya meninggal dunia, beliau tumbuh dan berkembang sebagai wirausahawan yang mandiri dengan melakukan perdagangan keliling di kota Makkah dengan rajin, penuh dedikasi pada usahanya (Syahrial, 2011: 76-77).

Kecerdasan/fathonah, kejujuran/siddiq, dan kesetiaannya memegang janji/amanah, adalah sebagai dasar etika wirausaha yang sangat modern. Dari sifat-sifat yang dimilikinya itulah maka berbagai pinjaman komersial/commercial loan tersedia di kota Makkah, yang pada gilirannya membuka peluang antara Muhammad dengan pemilik modal. Salah seorang pemilik modal terbesar ketika itu adalah seorang janda kaya bernama Khadijah, yang memberikan tawaran suatu kemitraan berdasarkan pada sistem bagi hasil/profit sharing atau mudharabah. Kecerdasan Muhammad sebagai seorang wirausahawan telah 
mendatangkan keuntungan besar bagi Khadijah, karena tidak satupun jenis bisnis yang ditangani Muhammad mengalami kerugian. Lebih kurang dua puluh tahun Nabi Muhammad SAW berkiprah sebagai seorang wirausahawan, sehingga beliau sangat dikenal di Syria, Yaman, Basra (Iraq), Yordania dan kota-kota perdagangan di jazirah Arabia. Dalam berbagai telaah sejarah diriwayatkan bahwa Muhammad memulai perdagangannya pada usia tujuh belas tahun di saat Abu Thalib menganjurkan untuk berdagang sebagai cara melepaskan beban keluarga pamannya dan beliau sendiri. Adalah normal bagi seorang pemuda yang jujur dan penuh idealisme untuk melakukan kerja keras dengan menjalankan perdagangan secara adil dan atas dasar suka sama suka. Dengan cara itu Nabi Muhammad SAW percaya bahwa kalau ia jujur, setia dan profesional, maka orang akan mempercayainya. Inilah dasar kepribadian dan etika berwirausaha yang diletakkan Nabi Muhammad SAW kepada umatnya dan seluruh umat manusia. Dasar-dasar etika wirausaha yang demikian itu pula, kemudian yang menyebabkan pengaruh Islam berkembang pesat sampai ke pelosok bumi.

Dari sudut pandang ekonomi, ajaran dan keteladanan yang ditinggalkan Nabi Muhammad SAW semakin terasa urgensi dan relevansinya, jika mencitacitakan terwujudnya masyarakat yang adil dalam kemakmuran, dan makmur dalam berkeadilan. Prinsip bisnis modern seperti efisiensi, transparansi, persaingan sehat, kredibilitas, memelihara relasi melalui layanan manusiawi, dapat ditemukan dalam etika dan perilaku bisnis Nabi Muhammad SAW sebelum menjadi Rasul. Etika bisnis memegang peranan sangat penting, jika seseorang atau sekelompok orang memegang peranan yang menentukan nasib bisnis orang lain atau masyarakat yang lebih luas, dan mereka inilah yang disebut pemimpin atau lapisan kepemimpinan dunia usaha. Relevansi etika bisnis dan efisiensi dapat digambarkan secara sederhana. Jika seorang pemimpin menyalahgunakan wewenang yang dimilikinya, pasti ada yang menjadi korban. Karena wewenang yang dimiliki bersifat publik, maka rakyatlah yang dirugikan, yang pada gilirannya akan meningkatkan biaya ekonomi yang tinggi. Dalam kurun waktu sebelum diangkat menjadi Rasul, Nabi Muhammad SAW telah meletakkan dasar-dasar etika, moral dan etos kerja yang mendahului zamannya. Dasar-dasar etika wirausaha tersebut kemudian telah mendapat legitimasi keagamaan setelah beliau diangkat menjadi Rasul. Prinsip-prinsip etika bisnis wirausaha yang diwariskan beliau dan Islam juga semakin mendapat pembenaran akademis.

Dari sudut pandang ekonomi, era global ditandai dengan aktivitas 
ekonomi baru, yakni perdagangan bebas dan pasar global. Berbagai kawasan dunia akan menjadi pasar dagang dan lahan investasi international secara bebas dan terbuka. Karenanya setiap individu umat Islam harus mulai berpikir dan berinteraksi dengan individu atau kelompok untuk berwirausaha dan menjalin kerjasama dalam bentuk kemitraan maupun persaingan sebagaimana saudara-saudara kita dari suku China yang telah sukses dan menjadi pengendali wirausaha di negeri ini.

Allah SWT memberikan petunjuk dalam al Quran yang artinya sebagai berikut:

"Apabila telah ditunaikan shalat, maka bertebaranlah kamu di muka bumi, dan carilah karunia Allah, dan ingatlah Allah sebanyak-banyaknya agar kamu beruntung" (QS al Jum'ah: 10)

Firman Allah pada ayat di atas, sebenarnya memberikan motivasi yang begitu kuat bagi umat Islam untuk bekerja dan berwirausaha. Rasulullah SAW bersabda: "Tiada seorang yang makan makanan yang lebih baik dari makanan dari hasil usahanya sendiri (wirausaha). Sesunggunya Nabi Allah Daud, itupun makan dari hasil usahanya sendiri (wirausaha)" (HR Bukhari).

\section{Membangun Konsep Enterpreneurship Islam}

Bekerja dan berusaha, termasuk berwirausaha, boleh dikatakan merupakan bagian tak terpisahkan dari kehidupan manusia, karena keberadaannya sebagai khalifah fil ardh dimaksudkan untuk memakmurkan bumi dan membawanya ke arah yang lebih baik, seperti dalam al Quran yan artinya:

"...Dia Telah menciptakan kamu dari bumi (tanah) dan menjadikan kamu pemakmurnya [Maksudnya: manusia dijadikan penghuni dunia untuk menguasai dan memakmurkan dunia.], ... "(QS Hud: 61).

Kewirausahaan (entrepreneurship) adalah suatu usaha yang kreatif yang membangun suatu value dari yang belum ada menjadi ada dan bisa dinikmati oleh orang banyak (Hendro, 2011: 21). Pengertian lain wirausaha diidentikkan dengan wiraswasta, sehingga "wirausahawan" dapat disebutkan sebagai orang yang pandai atau berbakat mengenal produk baru, menentukan cara produksi baru, dan menyusun pedoman operasi untuk pengadaan produk baru, memasarkannya, serta mengatur permodalan operasinya (Suryanto, 1977: 215).

Suatu kenyataan bahwa aktifitas berwirausaha merupakan bidang kehidupan yang kurang berkembang secara memuaskan di kalangan masyarakat pribumi atau masyarakat muslim Indonesia. Banyak faktor psikologis yang membentuk sikap negatif masyarakat terhadap profesi wirausaha. Pertama, 
image lama yang melekat pada orang yang aktif pada bidang ini, antara lain sifat agresif, ekspansif, bersaing tidak jujur, kikir, dan sumber penghasilan tidak stabil. Image ini menyebabkan sebagian besar masyarakat Indonesia tidak tertarik untuk berwirausaha. Para orang tua, sebagian besar menginginkan anaknya menjadi pegawai negeri, pegawai di perusahaan swasta terkenal, jadi insinyur, dokter, pilot, tentara dan jabatan-jabatan keren lainnya. Hampir tidak ada yang menginginkan anaknya jadi wirausahawan. Kalaupun ada yang berminat, sangat terbatas di kalangan mereka yang tidak diterima di perguruan tinggi, pegawai, tentara dan sebagainya.

Kedua, sikap tidak tertarik pada kegiatan wirausaha itu juga dipicu oleh pemahaman yang terlalu simplistic (dangkal) terhadap ajaran agama, khususnya hadits-hadits yang secara sepintas dipahami seakan-akan tidak mementingkan kesuksesan di dunia, misalnya: "Dunia ini penjara bagi orang yang beriman, dan surga bagi orang kafir", (al Hadits). Padahal ini seharusnya diartikan secara luas, "penjara" itu diartikan ada aturan-aturan syariah (hukum Islam). Sebuah cerita Husen bin Ali dengan orang Yahudi. Suatu hari Husen bin Ali mengendarai kuda yang sangat bagus dan pilihan (kalau sekarang mungkin BMW, atau mungkin merek kendaran lain yang sangat mewah), lalu Yahudi tersebut mengungkapkan hadits di atas kepada Husen bin Ali, disangkal oleh Hasan bin Ali dengan argumentasi di atas.

Di samping itu juga ditemukan ajaran-ajaran agama, khususnya di dunia tasawuf dan tarekat yang jika dipahami secara sempit, akan cenderung mengecilkan arti prestasi keduniaan, seperti zuhud, wara, faqir dan sebagainya. Kondisi yang memprihatinkan akibat tradisi dan pemahaman ini, akhirnya membuat anak negeri kurang menyentuh kewirausahaan, dan pada gilirannya menyebabkan negeri kita sangat tertinggal bila dibandingkan dengan negaranegara seperti Singapura, Jepang, Korea, Hongkong bahkan Malaysia, di mana negara tersebut mempunyai masyarakat yang memiliki jiwa wirausaha yang sangat tinggi.

Berangkat dari dasar pemikiran itu, maka pengembangan dan penumbuhan jiwa kewirausahaan merupakan tugas yang inhern dalam agama, dan juga merupakan salah satu alternatif bagi pemulihan krisis ekonomi dan lapangan kerja yang masih melilit bangsa kita.

Paling tidak, ada dua alasan mengapa kewirausahaan perlu dikembangkan di Indonesia, dengan penduduk yang mayoritas muslim ini. Pertama, kenyataan dari sejumlah angkatan kerja yang ada, masih sangat sedikit yang tertampung dalam lapangan kerja, sehingga pembukaan lapangan kerja baru menjadi suatu 
keniscayaan dalam pemberdayaan masyarakat Indonesia.

Kedua, Nabi Muhammad SAW yang merupakan ikutan dan teladan bagi umat Islam, komunitas terbanyak negeri ini, adalah seorang pedagang yang sangat ulet dan professional, jujur, memegang amanah, dan terpercaya. Bahkan kredibilitas dan integritas pribadinya sebagai pedagang mendapat pengakuan bukan hanya dari kaum muslimin, tetapi juga orang Yahudi dan Nasrani, dikarenakan Nabi menjalankan usahanya dengan sangat profesional.

\section{Berusaha Bagian Integral dari Kehidupan Umat Islam}

Sebagai agama yang menekankan dengan kuat sekali tentang pentingnya keberdayaan umatnya, maka Islam memandang bahwa berusaha atau berwirausaha merupakan bagian integral dari ajaran Islam. Terdapat sejumlah ayat dan hadits Nabi Muhammad SAW yang menjelaskan pentingnya aktifitas berusaha itu, diantaranya:

"Apabila telah ditunaikan sholat, maka bertebaranlah di muka bumi. Dan carilah karunia Allah" (QS al Jumuah: 10).

"Sungguh seandainya salah seorang di antara kalian mengambil beberapa utas tali, kemudian pergi ke gunung, kemudian kembali memikul seikat kayu bakar dan menjualnya, kemudian dengan hasil itu Allah mencukupkan kebutuhan hidupmu, maka itu lebih baik daripada meminta-minta kepada sesama manusia, baik mereka memberi maupun tidak" (HR Bukhari).

Pernah suatu saat Rasulullah ditanya oleh para sahabat, "pekerjaan apa yang paling baik ya Rasulullah?" Rasulullah menjawab, "seorang bekerja dengan tangannya sendiri dan setiap jual beli yang bersih" (HR al Bazzar) "Pedagang yang jujur lagi terpercaya adalah bersama-sama Nabi, orang-orang shadiqin, dan para syuhada"(HR Tirmidzi dan Ibnuu Majah).

"Perhatikan olehmu sekalian, sesungguhnya perdagangan itu di dunia ini adalah sembilan dari sepuluh pintu rezeki" (HR Ahmad).

Ayat dan hadits-hadits di atas memperlihatkan bagaimana kewirausahaan merupakan aktifitas yang inhern dalam ajaran Islam. Sedemikian strategisnya kedudukan kewirausahaan dan perdagangan dalam Islam, sehingga teologi Islam itu dapat disebutkan sebagai "teologi perdagangan" (commercial theology). Hal tersebut dapat dilihat dari kenyataan bahwa: Hubungan timbal balik antara Tuhan dan manusia bersifat perdagangan betul, Allah SWT adalah saudagar Maha Sempurna. Dia (Allah SWT) memasukkan seluruh alam semesta dalam pembukuan-Nya. Segalanya diperhitungkan, tiap barang diukur. Ia (Allah SWT) telah membuat buku perhitungan, neraca-neraca, dan Dia (Allah SWT) telah menjadi contoh buat bisnis-bisnis yang jujur.

Pengembangan kewirausahaan di kalangan masyarakat Indonesia 
memiliki manfaat yang terkait langsung dengan pengembangan masyarakat. Manfaat tersebut, antara lain: Pertama, pengembangan kewirausahaan akan memberikan konstribusi yang besar bagi perluasan lapangan kerja, sehingga dapat mengurangi angka pengangguran.

Kedua, berkembangnya kewirausahaan akan meningkatkan kekuatan ekonomi negara. Telah terbukti dalam sejarah perjalanan bangsa kita bahwa Usaha Kecil Menengah (UKM) adalah basis ekonomi yang paling tahan menghadapi goncangan krisis yang bersifat multidimensional.

Ketiga, dengan semakin banyaknya wirausahawan, termasuk wirausahawan muslim, akan semakin banyak tauladan dalam mayarakat, khususnya dalam aktifitas perdagangan. Sebab para wirausahawan memiliki pribadi yang unggul, berani, independen, hidup tidak merugikan orang lain, sebaliknya malah memberikan manfaat bagi anggota masyarakat yang lain.

Keempat, dengan berkembangnya kewirausahaan, maka akan menumbuhkan etos kerja dan kehidupan yang dinamis, serta semakin banyaknya partisipasi masyarakat terhadap pembangunan bangsa.

\section{Sifat-Sifat Dasar Wirausaha Muslim}

Sebagai konsekuensi pentingnya kegiatan wirausaha, Islam menekankan pentingnya pembangunan dan penegakan budaya kewirausahaan dalam kehidupan setiap muslim. Budaya kewirausahaan muslim itu bersifat manusiawi dan religius, berbeda dengan budaya profesi lainnya yang tidak menjadikan pertimbangan agama sebagai landasan kerjanya.

Seorang wirausahawan muslim akan memiliki sifat-sifat dasar yang mendorongnya untuk menjadi pribadi yang kreatif dan handal dalam menjalankan usahanya, atau menjalankan aktivitas pada perusahaan tempatnya bekerja. Sifat-sifat dasar itu, diantaranya ialah:

Pertama, Selalu menyukai dan menyadari adanya ketetapan dan perubahan. Ketetapan ditemukan antara lain pada konsep aqidah, seperti dalam al Quran yang artinya:

"Dan kami tidak mengutus seorang rasulpun sebelum kamu melainkan kami wahyukan kepadanya: "Bahwasanya tidak ada Tuhan (yang hak) melainkan aku, Maka sembahlah olehmu sekalian akan aku" (QS al Anbiya: 125).

Sedangkan perubahan dilaksanakan pada masalah-masalah muamalah, termasuk peningkatan kualitas kehidupan:

"... Sesungguhnya Allah tidak merubah keadaan sesuatu kaum sehingga mereka merubah keadaan (Tuhan tidak akan merubah keadaan mereka, selama 
mereka tidak merubah sebab-sebab kemunduran mereka) yang ada pada diri mereka sendiri..." (QS al Ra'd: 11).

Kedua, Bersifat inovatif, yang membedakannya dengan orang lain. Dalam hal ini al Quran menempatkan manusia sebagai khalifah, dengan tugas memakmurkan bumi, dan melakukan perubahan serta perbaikan (al Hadits).

Ketiga, Berupaya secara sungguh-sungguh untuk bermanfaat bagi orang lain. Ada beberapa hadits Nabi yang menjelaskan keharusan seseorang untuk bermanfaat bagi orang lain.

\section{Memulai Usaha dengan Menata Keluarga Dahulu}

Keluarga merupakan hal yang tak terpisahkan dari dunia bisnis/usaha. Permasalahan keluarga akan berpengaruh pada maju mundurnya suatu usaha. Ibaratnya, keluarga dan bisnis adalah dua sisi mata uang yang tidak bisa dipisahkan. Karenanya, ketika akan mengawali usaha kita harus menata keluarga terlebih dulu. Anggota inti keluarga hendaknya bisa memahami tentang dunia usaha yang dipilih. Pemahaman ini akan mengurangi kemungkinan terjadinya konflik dalam keluarga. Menata keluarga yang baik adalah bagaimana menjalankan roda kehidupan keluarga berdasarkan al Quran dan Sunnah Nabi. Apabila anggota keluarga telah menjalankan kewajiban dan memperoleh haknya, Insya Allah, akan terwujud keluarga sakinah. Suami mempunyai hak dan kewajiban (akhlaq suami), istri juga mempunyai hak serta kewajiban (akhlaq istri). Selain itu juga ada hak dan kewajiban orang tua (akhlaq orang tua) dan hak serta kewajiban anak kepada orang tuanya (akhlaq anak). Semuanya telah diatur dalam Islam. Apabila kesemuanya bisa berjalan dengan baik dan benar, berarti kehidupan keluarga bisa berjalan dengan landasan akhlaqul karimah. Pada keluarga yang demikian, apabila menjalankan sebuah usaha Insya Allah kemungkinan suksesnya lebih besar.

\section{Simpulan}

Sebagai konsekuensi pentingnya kegiatan wirausaha, Islam menekankan pentingnya pengembangan dan penegakan budaya kewirausahaan dalam kehidupan setiap muslim. Budaya kewirausahaan muslim itu bersifat manusiawi dan religius, berbeda dengan budaya profesi lainnya yang tidak menjadikan pertimbangan agama sebagai landasan kerja. Dengan demikian, seorang wirausahawan muslim akan memiliki sifat-sifat dasar yang mendorong untuk menjadi pribadi yang kreatif dan handal dalam menjalankan usahanya atau 
aktifitas pada perusahaan tempatnya bekerja. Sifat-sifat dasar itu di antaranya, sebagai berikut: (1) Selalu menyukai dan menyadari adanya ketetapan dan perubahan. Ketetapan ditemukan antara lain pada konsep akidah. Sedangkan perubahan dilaksanakan pada masalah-masalah muamalah, termasuk peningkatan kualitas kehidupan, (2) Bersifat inovatif, yang membedakannya dengan orang lain. Al Quran menempatkan manusia sebagai khalifah dengan tugas memakmurkan bumi, dan melakukan perubahan serta perbaikan, (3) Berupaya secara sungguh-sungguh untuk bermanfaat bagi orang lain, disebutkan dalam hadits Nabi SAW yang menjelaskan keharusan seseorang bermanfaat bagi orang lain.

Karakter dan kepribadian karyawan dibentuk secara berkelanjutan, bukan hanya untuk sesaat atau untuk dirinya sendiri, atau orang sesamanya. Tetapi juga untuk jangka yang lebih panjang, bagi generasi-generasi sesudahnya. Bukan hanya diusahakan berjalan secara baik pada masanya, namun juga sesudahnya. Jadi dibutuhkan pelembagaan bagi sistem kerja para karyawan.

Dalam berbagai nash (ayat dan hadits), ditemukan bahwa karakter inti seorang wirausahawan muslim akan terlihat dalam kaitannya dengan delapan hal, yaitu: (1) Motif atau niat dalam melaksanakan usaha, (2) Pandangan terhadap status. (3) Pandangan terhadap siapa yang harus dilayani, (4) Sikap terhadap system, (5) Sikap terhadap pelaksanaan kerja, (6) Sikap terhadap kesalahan atau kegagalan, (7) Keahlian dan skill, (8) Karakter dan profesionalisme.

Motivasi seorang wirausaha muslim bersifat horizontal dan vertikal. Secara horizontal terlihat pada dorongannya untuk mengembangkan potensi diri dan keinginannya senantiasa mencari manfaat sebanyak-banyaknya untuk orang lain. Sementara secara vertikal dimaksudkan untuk mengabdikan diri kepada Allah SWT. Motivasi disini berfungsi sebagai pendorong, penentu arah, dan penetapan skala prioritas.

Berdasarkan prinsip itu, maka seorang wirausahawan muslim harus memiliki mental yang tangguh dalam menghadapi segala tantangan, keyakinan yang tinggi bahwa ia dapat mengatasi segala tantangan dan kegagalan yang ada. Dari analisis di atas, jelaslah bahwa Islam mengajarkan nilai-nilai yang bermanfaat bagi pengembangan dirinya dan bermanfaat bagi orang lain di sekitarnya.

\section{Daftar Pustaka}

Al Quran Digital. 2011.

Al Hadits Digital. 2011. 
Geertz, Clifford. 1960. The Religion of Java. London: University of Chicago Press.

Hendro. 2011. Be a Smart \& Good Entrepreneur. Yogyakarta: Med Press.

Pulungan, Fachrurrozy. 2009. Artikel Skema Pengembangan Entrepreneurship dan Usaha Kecil Melalui Program Inkubator Bisnis di Perguruan Tinggi: 10 Langkah Memulai Usaha Sendiri. Medan: TP.

Rais, M. Amien dan Sasono, Adi. 1986. Islam di Indonesia, Suatu Ikhtiar Mengaca Diri. Jakarta: Rajawali Press.

Syahrial, Muhammad. 2011. Anakku Maukah Kau Jadi Pengusaha?. Jakarta: TP.

Suryanto, dkk. 1977. Kamus Lengkap Bahasa Indonesia. Surabaya: Apollo. 